Juan de Mandevilla.

Libro de las maravillas

del mundo y del Viaje

de la Tierra Sancta de

Jerusalem (Impresos

castellanos del siglo XVI)

María Mercedes

Rodríguez TEMPERley (ED.)

libicrit Secrit, Buenos Aires, 2011.

\section{Rodríguez Temperley y su trabajo}

\author{
María del Rosario Keba • \\ Universidad Nacional del Litoral
}

La reconocida investigadora y especialista María Mercedes Rodríguez Temperley publicó en 2005 la única versión aragonesa de fines del siglo XIV del manuscrito del Libro de las Maravillas del mundo de Juan Mandevilla conservada en España. En 2011 nos presenta la edición del libro en sus distintas versiones impresas que circularon durante el siglo XVI. Esto habla de su constante interés por la obra y pone de manifiesto lo ardua que debió ser la tarea, sólo basta con observar cada uno de los comentarios que aporta a lo largo de las 314 páginas. Un párrafo aparte merece el cuidadoso trabajo del prólogo que nos ofrece, en él no deja lugar a dudas el tiempo, la atención y la observación minuciosa con que encaró la tarea. A través de este prólogo el lector comprende que el manejo atento de las fuentes, los cotejos de información han sido el capital necesario que le han permitido llegar a realizar los cuadros comparativos que nos presenta en la última parte. De la lectura del prólogo también surge con nitidez el apasionamiento con que encaró un análisis tan cuidadoso como preciso.

Es dable destacar que el acercamiento de Rodríguez Temperley por este autor cuenta con un largo camino recorrido y es posible señalar el año 1999 como el punto de inicio. En su Estudio Preliminar de la edición que nos convoca explicita el recorrido que llevó adelante y cuáles han sido sus propósitos de análisis para la versión de Mandevilla del siglo XVI. La mueve el propósito de analizar la obra desde una perspectiva integradora que contemple tanto la etapa manuscrita como la impresa. Esto le facilita el cotejo, la comparación entre una y otra estrategia necesaria que sustenta los análisis que propone.

Debemos señalar como un factor decisivo y caracterizador de la edición que nos trae, el marcado interés por el análisis tanto de las imágenes como de la relación que éstas guardan con los textos. Para la investigadora resulta necesario analizar todos aquellos signos no verbales que acompañan el texto ya que permiten abrir luz sobre aspectos fundamentales que hacen a la interpretación y difusión de las versiones castellanas. Atender a estas signos no verbales deviene de lo que para la editora es, podríamos pensar, un requerimiento metodológico.

- Profesora en Letras por la Universidad Nacional del Litoral. Desempeña funciones en Literatura Española I y Literatura Española Il en las carreras de Profesorado y Licenciatura en Letras de la Facultad de Humanidades y Ciencias de la Universidad Nacional del Litoral. Participa en proyectos CAID $+D$. Actualmente cursa su doctorado y ha participado en distintos congresos o coloquios referidos a su área de trabajo. 
La edición de la que damos cuenta se organiza en tres partes. La primera se subdivide en Prefacio, Introducción y tres módulos centrales de análisis además del referido a Bibliografía. Con relación al primero de los módulos lo denomina Panorama Crítico. En él desarrolla un estudio al que organiza en cuatro divisiones. El primer tramo aborda cuestiones vinculadas al horizonte crítico de la difusión del libro. Al segundo lo denomina Impresos conservados. Aquí focaliza en cinco puntos tendientes a describir las distintas ediciones tomando como primera fecha la del año 1521 para reconstruir las mismas. Este abordaje resulta un aporte interesante sobre el rol que tuvo la imprenta en el funcionamiento del texto. Al tercer módulo lo llama Imprenta y variación textual: el caso de Juan de Mandevilla. En lo que respecta a la segunda parte, ésta hará centro en lo que llama Texto Crítico. Resultan importantes las explicaciones iniciales que ofrece bajo el título La presente edición, allí le explicita al lector desde qué lugar encarará la tarea de anotaciones y aclara los criterios organizativos. La tercera y última parte está asociada a los anexos. Estos últimos ofrecen cuadros comparativos de suma importancia en tanto que demuestran el cuidadoso y riguroso análisis que llevó adelante. Dejan leer los cambios diacrónicos, esto brinda al lector una perspectiva histórica y lingüística altamente productiva. También como otros dos componentes de la tercera parte aparecen el Glosario y el Índice, éste está subdividido en tres partes (Onomástico, Topónimos y Palabras extranjeras).

Destacar la organización de esta edición no hace más que poner de relieve lo valioso que resulta para los estudiosos de este campo de la literatura. También debe llamar la atención el trabajo y los aportes que ofrece el prólogo dado que combina con equilibrio el caudal de datos que ha recogido a través del rastreo de diversas fuentes consultadas con las conclusiones a las que arriba a través del cruce de ellas con las versiones recogidas.

Por todo lo señalado, tanto críticos como lectores de libros de viaje encontrarán en esta edición, sin lugar a dudas, un territorio fértil para disfrutar de todas y cada una de las páginas. 